若林良和著

\title{
『水産社会論一一カオオ漁業研究による 「水産社会学」の確立を目指して』
}

(御茶の水書房, 2000 年, A5 判, 406頁, 7,000円)

鳥越 皓之

(筑波大学教授)

村落社会研究は，わが国社会学において，かなりの長い期間，重要な位置を占 めてきた。そしてこの分野は社会学としてはめずらしく，著作集を出す社会学者 を多く輩出した。なぜ村落社会学がそれほどまでに重要な位置を占めてきたかと いうと，もちろん当時の日本社会において，農業・漁業村落そのものが大切であ ったということもあろうが，なによりも緻密な実証的分析が他の分野を圧倒して いたことにあると思われる，緻密な実証である割には，その理論が地味であるこ とから “燻し銀”のような論文の蓄積というやや挪揄を込めた評価を他の分野の 社会学者から出されるということもあったが, その理論は社会学内に止まらず, 他の学問分野に多大の影響を与えた.

なぜ，このような村落社会学についての一般的な記述を冒頭においたのかとい うと, じつは本書は, 村落社会学の緻密実証的で地味な理論という“燻し銀”を 久しぶりに再現した重みのある著書であると評者は思ったからである．15年以上 にわたる漁業社会についての長期的な調査，カツオ船に乗り込んでの現場の緻密 な調査, その割には謙虚な（つまりは地味な）論理展開と結論という，まさに村 落社会学の“王道”を再現している。

本書は「ソロモン諸島に扔ける合弁カツオ漁業」をあつかった第 1 部と,「日本 における近海カツオ漁業」をあつかった第2部とに大きくふたつに分かれている. しかし共にカツオ漁をあつかっているのと分析視角が同じであるために違和感は ない.

本書の最大の特色は, じつは漁村社会学ではなくて水産社会学であることであ る。それは農村社会学研究のなかに最近，農業社会学的研究が増えてきているの と傾向を一にしている。すなわち，農村や漁村という「村落」を対象にしている のではなくて，水産という産業を対象にしていることである。これは当然な，ま た，望ましい傾向と評者は見る。しかしそのことは，本書において村落社会学の 膨大な蓄積の研究史のほとんどを利用できないという欠点を意味する。その結果， 本書をいわば “孤独な”研究とさせ，言葉を換えると，村落社会学の諸理論との 格闘がないために，本書はやや浅い論理展開とならざるを得ない宿命を担うこと になってしまった。

本書はカツオ漁業を対象として「漁撈集団」と「海上生活構造」の把握を具体 
的な目的とし，ソロモン諸島と日本で分析を抗こなっている.ソロモンでは，日 本とソロモン諸島との合弁会社で，合弁の成功例としてのSTL（Solomon Taiyo Ltd.）をとりあげている。ソロモン群島の漁業開発の歴史と現状についての膨大 で丁寧な記述がある．評者としてはその記述の後の, ソロモンの漁民相互やソロ モン人と日本人との間の人間関係の記述に興味をもった。たとえばピジン英語で ワントク (one talk，ひとつの言語）という言葉があり，それは同一の言語を使用 する伝統的な部族集団や仲間のことを意味する。なにかの理由で都市生活を断念 した者は村に戻るが，そこはワントク的共同社会で，そこでは共同作業に参加す る限り衣食住が保証されるいわば相互補助組織なのである。ソロモンの漁民は背 景にワントクを背負って船団を構成しているのだそうで, さらに著者は論を進め て, 日本の南方カツオ漁業自体も見方によればワントク的側面が船団に存在する という。それを南方カツオ業基地である沖縄県伊良部町で実証している.

日本人漁労長を中心とする日本人とソロモン人やフィリピン人に対する配慮や 船内でのカツオ漁の分担や指揮命令系統，また衣食住にわたる個別の記述も興味 をそそるし，それらの記述は資料的価值が高い.

本書全体としては，わが国の漁撈集団に抢ける親族関係の重要さなど，十分予 想できることではあるものの大切な指摘が各所にみられて, 水産社会学の今後の 展望にとって大切な研究である印象をもった，ただ，事実と説明（理論化）との 間に，そうかなという疑問を挟まざるを得ない飛躍がときにみらえるように思わ れる．たとえば漁撈集団に親族関係者が多くを占める解釈として，すでに先学に よって指摘されたもの一一たとえば漁業は生命の危険性が高いので緊密性が要求 される——というような解釈をそのまま受け入れているところなど, 農業など生 命の危険のない分野でも親密な親族労働組織があり, その研究がかなり進んでい る現状では，安易な説明に小さな不満が残る。他分野の研究史への目配りが望ま れる.ともあれ，水産社会学研究史に残る貴重な研究であることはまちがいない. 